\title{
Jurist-Diction
}

Volume 4 No. 1, Januari 2021

\section{Pengaturan Harmonisasi Rancangan Peraturan Perundang- Undangan yang Dibentuk Di Daerah oleh Kemenkumham}

\author{
Choirudin Abdul Ghoni \\ choirudin.abdul.ghoni-2016@fh.unair.ac.id \\ Universitas Airlangga
}

How to cite:

Choirudin Abdul Ghoni,

'Pengaturan Harmonisasi Rancangan Peraturan

Perundang-Undangan yang Dibentuk Di Daerah oleh

Kemenkumham' (2021) Vol. 4

No. 1 Jurist-Diction.

Histori artikel:

Submit 12 November 2020; Diterima 09 Desember 2020; Diterbitkan 5 Januari 2021.

DOI:

10.20473/jd.v4i1.24293

p-ISSN: $2721-8392$

e-ISSN: $2655-8297$

\section{Abstract}

In accordance with the many existing laws and regulations, it is possible that such occurrence lead to the emergence of overlapping and conflicting laws and regulations. This paper intends to examine the validity of Minister of Law and Human Rights Regulation No. 22 of 2018 concerning harmonizing the legislation draft established in the regions by the regulator. This paper refers to the type of legal research using library studies as method, with the concept and legal approach, and using descriptive analysis in its writing. Through this paper, it was found that Minister of Law and Human Rights Regulation No. 22 of 2018 is invalid because the legal basis and authority for harmonization are not based on the substance of the elaboration of the existing higher legislation and the regulation, it has also ruled out the higher legal norms which related to the limits of authority harmonization of law regulations that are formed in the regions. Therefore, it is recommended that the Ministerial Regulation be ordered by higher legislation or formed based on authority that does not conflict with higher norms. The harmonization authority by the Ministry of Law and Human Rights is only limited to regional regulations originating from the Governor, Regents and Mayors without including regulations regions from the Provincial DPRD, Regency DPRD, and City DPRD as well as other legal products formed in the regions.

Keywords: Minister of Law and Human Rights; Minister of Law and Human Rights Regulation No. 22 of 2018; Harmonization.

\begin{abstract}
Abstrak
Seiring dengan banyaknya keberadaan peraturan perundang-undangan yang berlak'ud ingin mengkaji keabsahan Peraturan Menteri Hukum dan HAM Nomor 22 Tahun 2018 tentang pengharmonisasian rancangan peraturan perundang-undangan yang dibentuk di daerah oleh perancang. Penulisan ini mengacu pada jenis penelitian hukum dengan menggunakan studi kepustakaan, dengan pendekatan konsep dan pendekatan perundang-undangan, serta menggunakan analisis deskriptif. Melalui penulisan ini didapatkan bahwa Peraturan Menteri Hukum dan HAM Nomor 22 Tahun 2018 tidak sah karena dasar hukum dan wewenang untuk harmonisasi tidak didasari substansinya atas penjabaran perundang-undangan yang lebih tinggi dan aturan tersebut telah mengesampingkan norma hukum yang lebih tinggi diatasnya terkait batasan wewenang harmonisasi peraturan perundang-undangan yang dibentuk di daerah. Dengan demikian, disarankan Peraturan
\end{abstract}




\begin{abstract}
Menteri tersebut harus diperintahkan oleh Peraturan Perundangundangan yang lebih tinggi atau dibentuk berdasarkan kewenangan yang tidak bertentangan dengan norma yang lebih tinggi serta wewenang harmonisasi oleh Kemenkumham hanya sebatas peraturan daerah yang berasal dari Gubernur, Bupati, dan Walikota tidak termasuk peraturan daerah dari DPRD Provinsi, DPRD Kabupaten, dan DPRD Kota serta produk hukum lainnya yang dibentuk di daerah. Kata Kunci: Kementerian Hukum dan HAM; Peraturan Menteri Hukum dan HAM Nomor 22 Tahun 2018; Harmonisasi.
\end{abstract}

Copyright (C) 2021 Universitas Airlangga

\section{Pendahuluan}

Seiring dengan banyaknya keberadaan peraturan perundang-undangan yang berlaku dapat menimbulkan munculnya peraturan perundang-undangan yang saling tumpang tindih serta saling bertentangan maka seiring dengan berjalannya waktu akan menimbulkan ancaman pada kepastian hukum, selain kepastian hukum juga akan mengurangi waktu dan tenaga untuk memahami aturan yang berlaku. ${ }^{1}$ Dalam hal ini terkait penetapan Permenkumham Nomor 22/2018 yang ditindaklanjuti dengan dikeluarkannya Surat Edaran Direktur Jenderal Peraturan Perundang-undangan Nomor PPE.PP.01.03-472 Tahun 2018 menarik perhatian dan mengagetkan banyak pihak khususnya bagi perancang peraturan perundang-undangan dan biro hukum seluruh Pemerintah Daerah. ${ }^{2}$ Melalui peraturan ini, kegiatan pengharmonisasian rancangan peraturan daerah provinsi, rancangan peraturan daerah kabupaten/kota, rancangan peraturan gubernur, rancangan peraturan bupati/walikota, rancangan peraturan desa atau yang setingkat, dan peraturan kepala desa atau rancangan peraturan yang setingkat yang dulunya dilaksanakan oleh masing-masing Pemerintah Daerah kini harus diharmonisasikan melalui Direktorat Jenderal Peraturan Perundang-undangan, Kementerian Hukum dan Hak Asasi Manusia. Konsekuensi terhadap Pemerintah Daerah yang peraturan perundang-undangannya telah ditetapkan oleh pimpinan lembaga tetapi tidak melalui proses harmonisasi di Kementerian Hukum dan Hak Asasi Manusia maka tidak dapat diundangkan dalam

\footnotetext{
${ }^{1}$ E. Prajwalita Widiati dan N.Aji Utomo, Menjejakkan Legislasi Berbasis HAM (Komisi Nasional Hak Asasi Manusia 2016).[84].

2 Putusan Mahkamah Agung Nomor 15 P/HUM/2019 Perihal Hak Uji Materiil terhadap Peraturan Menteri Hukum dan Hak Asasi Manusia Republik Indonesia Nomor 23 Tahun 2018, 4 April 2019.
} 
Lembaran Daerah, Tambahan Lembaran Daerah, atau Berita Daerah Republik Indonesia. Disisi lain, menurut Kemenkumham berdasarkan wawancara Penulis kepada salah satu pegawai di Kanwil Kemenkumham Jawa Timur menyatakan alasan hukum dari Permenkumham Nomor 22/2018 secara singkat sesuai dengan konsideran yuridis Permenkumham tersebut melaksanakan Pasal 3 PP Nomor 59 Tahun 2015, pula untuk mengisi kekosongan wewenang penyusunan khususnya terkait pengharmonisasian, karena selama ini belum jelas siapa yang berhak atas pengharmonisasian peraturan perundang-undangan. Sedangkan alasan selain hukum ialah memperkuat keberadaan peran perancang peraturan perundang-undangan yang dibawah wewenang dirjen peraturan perundang-undangan Kemenkumham dengan tujuan terciptanya peraturan perundang-undangan yang selaras (harmoni) disektor horizontal dan selaras disektor vertikal antara pemerintah pusat maupun pemerintah daerah. ${ }^{3}$

Atas penetapan kebiajakan Kemenkumham diatas, Kemendagri meminta untuk mencabut Permenkumham Nomor 22/2018 dan Permenkumham No. 23 Tahun 2018 terkait pengharmonisasian peraturan daerah dan PP pusat ini. Kementerian Dalam Negeri (Kemendagri) mengajukan surat protes kepada Menkumham terkait terbitnya dua Permenkumham tentang harmonisasi peraturan perundang-undangan. Melalui surat Menteri Dalam Negeri No. 180/7182/SJ tanggal 19 September 2018 yang ditujukan kepada Menkumham, melalui Sekertaris jendral Kemendagri dikirimkan surat edaran kepada seluruh Sekretaris Daerah Provinsi/Kabupaten/ Kota bernomor 180/2190/Biro hukum tanggal 1 Oktober 2018 perihal mempertegas wewenang terkait tahapan/proses evaluasi dan fasilitasi penyusunan rancangan PERDA dan perkada. Kemudian ada juga informasi (beberapa) kementerian atau lembaga juga mempermasalahkan Permenkumham No. 23 Tahun 2018 ini. ${ }^{4}$ Selain itu, terdapat kegiatan perjalanan dinas yang dilakukan bagian fasilitasi telaahan

\footnotetext{
3 Wawancara dengan Anonim Pegawai Kemenkumham Kanwil Surabaya, Jawa Timur, 21 Februari 2020.

${ }^{4}$ Agus Sahbani,'Permenkumham Harmonisasi Peraturan Dinilai Konflik dengan UU' (2018)<www.Hukumonline.com/berita/baca/lt5bdc39c5d3a98/permenkumham-harmonisasiperaturan-dinilai- konflik-dengan-uu>, diakses pada 12 Agustus 2019.
} 
kebijakan Biro hukum Kemendagri contohnya di Biro hukum Provinsi Daerah Istimewa Yogyakarta, Biro hukum Provinsi Lampung, Biro hukum Jawa Barat, dan Bagian hukum Kabupaten Lombok Utara Provinsi NTB, bahwa dalam pembentukan produk hukum daerah yang dilakukan, telah melibatkan tenaga perancang dari Kanwil Provinsi Kemenkumham. Namun, apabila ditemukan pemerintah daerah belum melibatkan tenaga perancang dari Kanwil Provinsi Kemenkumham yang dapat dilakukan adalah mendorong dan mengingatkan pemerintah daerah untuk melaksanakan amanat dalam Peraturan Pemerintah Nomor 59 Tahun 2015 dan Peraturan Menteri Negeri Dalam Negeri Nomor 80 Tahun 2015 sehingga terhadap Permenkumham Nomor 22/2018 dimaksud dapat menimbulkan multi tafsir bagi pemerintah daerah atau dualisme pengaturan suatu norma/ketentuan yang telah diatur oleh peraturan perundang-undangan yang lebih tinggi atau setara. ${ }^{5}$

Kemendagri yang diwakili Mendagri mendasarkan pada kedudukan kementerian dalam negeri yang diakomodir oleh UU No 23 tahun 2014 Tentang Pemerintahan Daerah. Salah satunya ialah Pasal 8 Jo Pasal 373 UU No. 23 Tahun 2014 Tentang Pemerintah Daerah menyatakan “ Pemerintah pusat melalui Menteri Dalam Negeri mengkoordinasikan kegiatan pengawasan serta kegiatan pemibinaan terhadap penyelenggaraan urusan pemerintahan oleh daerah secara nasional" Berdasarkan Pasal 377 ayat (2) UU No. 23 Tahun 2014 Tentang Pemerintah Daerah : "Menteri teknis dan kepala lembaga pemerintah non kementerian melaksanakan pengawasan teknis terhadap penyelenggaraan Pemerintahan Daerah provinsi sesuai dengan bidang tugas masing-masing dan berkoordinasi dengan Menteri”. Pasal 58 ayat (2) UU 12 Tahun 2011 "Pengharmonisasian, pembulatan, dan pemantapan konsepsi Rancangan Peraturan Daerah Provinsi yang berasal dari Gubernur dikoordinasikan oleh Biro Hukum dan dapat mengikutsertakan instansi vertikal dari kementerian yang menyelenggarakan urusan pemerintahan di bidang hukum”.

5 Menteri Dalam Negeri,'Surat Edaran Permohonan Pencabutan Atas Permenkumham Nomor 22 Tahun 2018 dan Permenkumham Nomor 23 Tahun 2018'(2018)<http://jdih.setjen. kemendagri.go.id/materi/Surat\%20Permohonan\%20pencabutan\%20permenkumham.pdf $>$ diakses pada 12 Agustus 2019. 
Dalam ketentuan ini sangat jelas disebutkan bahwa pengharmonisasian peraturan daerah dikoordinasikan oleh Biro Hukum dan dalam pelaksanaannya tidak ada keharusan mengikutsertakan Kementerian Hukum dan HAM. Frasa "dapat” dalam ketentuan tersebut menunjukkan sifatnya yang fakultatif atau pilihan. UU No. 12 Tahun 2011 Pasal 58 ayat (2) perumusannya secara praktek/teknis telah sesuai dengan ketentuan Pasal 18 UUD NRI 1945 dan UU No. 23 Tahun 2014 Tentang Pemerintah Daerah. ${ }^{6}$ Pada tahun 2019 ketentuan Pasal 58 ayat (2) UU No 12 Tahun 2011 mengalami perubahan UU 15 Tahun 2019 Pasal 58 ayat (2) sebagai berikut: "Kementerian atau lembaga yang menyelenggarakan urusan pemerintahan di bidang Pembentukan Peraturan Perundang-undangan melaksanakan pengharmonisasian, pembulatan, dan pemantapan konsepsi Rancangan Peraturan Daerah Provinsi dan/atau kabupaten/kota yang berasal dari Gubernur dan/atau Bupati/walikota”. Sehingga yang pada awalnya biro hukum dari provinsi serta bagian hukum yang menyelenggarakan harmonisasi rancangan PERDA yang berasal dari gubernur, dan/ atau bupati/walikota digantikan oleh Kemenkumham dalam hal ini dilimpahkan kepada kanwil, akan tetapi ketentuan mengenai PERDA yang berasal dari usulan DPRD provinsi, dan/atau kabupaten/kota tetap pada alat kelengkapan yang ada di DPRD. Sedangkan, Menurut Kepala Biro Hukum Pemprov Jatim, Jempin Marbun, bahwa Permenkumham Nomor 22/2018 tentang harmonisasi produk hukum daerah itu memberikan dampak adanya dua lembaga yang memiliki wewenang pengawasan terhadap Peraturan Daerah (PERDA) Kabupaten/Kota dan Provinsi. ${ }^{7}$ Artinya, kalau selama ini wewenang tersebut menjadi tanggung jawab Mendagri tapi dengan adanya Permenkumham itu sekarang Menkumham melalui tim perancang juga akan ikut melakukan dalam proses harmonisasi PERDA. Jadi

6 Biro hukum Kemendagri, 'Kajian Normatif Permenkumham 22 Tahun 2018 Berdasarkan Peraturan Perundang-Undangan Dan Asas Hukum'(2018) < http:// keuda. kemendagri. go.id /asset /kcfinder /upload/ files/ Biro \% 20 Hukum\% 20 Kemendagri \% 20terkait\%20Permenkumham\%20 22\%20Tahun\%202018.pdf>, diakses 1 Agustus 2019.

7 Dinas Komunikasi dan Informasi Pemerintah Provinsi Jawa Timur,'Bapperda DPRD Minta Permenkumham No 22/2018 Tak Batasi Kebebasan Daerah'(2018) <http://kominfo.jatimprov.go.id/read/umum/bapperda-dprd-minta-permenkumham-no-22-2018-tak-batasi-kebebasandaerah>, diakses 12 Agustus 2019. 
sekarang ada dua lembaga yang mengatur hal yang sama, sehingga provinsi dan kabupaten/kota menjadi agak kebingungan. ${ }^{8}$ Pada tanggal 1 November 2018, Fakultas Hukum Universitas Indonesia mengadakan seminar bertajuk 'Quo Vadis, Tata Kelola Regulasi Indonesia? Telaah Akademis Peraturan Menteri Hukum dan Hak Asasi Manusia Republik Indonesia No 32 Tahun 2017, No. 22 Tahun 2018, No. 23 Tahun 2018' yang dihadiri oleh Prof. Dr. Maria Farida Indrati, S.H., M.H., Prof. Dr. Bagir Manan,,S.H., M.C.L., dan Dr. Wicipto Setiadi, S.H., M.H.,. Rekomendasi dari seminar tersebut bahwa para pakar hukum diatas bersepakat Peraturan Menteri Hukum dan Hak Asasi Manusia Republik Indonesia Nomor 22 Tahun 2018 melampaui kewenangan dan harus dilakukan judicial review di Mahkamah Agung. ${ }^{9}$ Berdasarkan PP Nomor 59 Tahun 2015 yang merupakan penjabaran lebih lanjut dari peraturan yang lebih tinggi yaitu berdasarkan Pasal 98 ayat (1) dan ayat (2) dan Pasal 99 UU Nomor 12 Tahun 2011 sebagaimana telah diubah dengan UU Nomor 15 Tahun 2019. Wewenang Menteri Hukum dan HAM Menurut PP Nomor 59 Tahun 2015 dalam Pasal 15 ayat (1) menyatakan bahwa Pembinaan terhadap jabatan Fungsional Perancang dilakukan oleh Menteri Hukum dan HAM Kemudian prosedur pelaksanaannya diatur diayat selanjutnya Pasal 15 ayat (2) Menteri Hukum dan HAM menugaskan kepala pimpinan tinggi madya/kepala yang setingkat bidang pembentukan peraturan perundang-undangan untuk melaksanakan pembinaan Fungsional Jabatan Perancang, Sementara itu didalam PP Nomor 59 Tahun 2015 Pasal 16 sampai dengan Pasal 17 diberikan tolak ukur untuk membuat dan mengatur mengenai pembinaan jabatan fungsional perancang. Serta mengatur pula mengenai wewenang pemerintah daerah terhadap perancang dalam Pasal 18:

"Pimpinan lembaga Negara, kementerian, lembaga pemerintah nonkementerian, lembaga nonstruktural, Pemerintah Daerah Provinsi, dan Pemerintah Daerah Kabupaten/Kota masing-masing melakukan Pembinaan karier Perancang yang berada di lembaga Negara, kementerian, lembaga pemerintah nonkementerian, lembaga nonstruktural, Pemerintah Daerah Provinsi, dan Pemerintah Daerah Kabupaten/Kota".

\footnotetext{
8 ibid.

9 Putusan Mahkamah Agung Nomor 15 P/Hum/2019 Op.Cit.
} 
Kedudukan Perancang Peraturan di dalam PP Nomor 59 Tahun 2015 sebagai pelaksana teknis fungsional Perancang pada unit kerja yang mempunyai tugas dalam Pembentukan Peraturan Perundang-undangan dan penyusunan instrumen hukum lainnya. Unit kerja yang dimaksud berada dilingkungan lembaga Negara, kementerian, lembaga pemerintah non kementerian, lembaga non struktural, Pemerintah Daerah Provinsi, dan Pemerintah Daerah Kabupaten/Kota. Pula menyiapkan, mengolah, dan merumuskan Rancangan Peraturan Perundangundangan serta instrumen hukum lainnya dan harus melakukan pengharmonisasian peraturan perundang-undangan Pengharmonisasian merupakan proses penyelarasan substansi dan teknik penyusunan peraturan perundang-undangan, sehingga menjadi peraturan perundang-undangan yang merupakan satu kesatuan yang utuh dalam kerangka sistem hukum nasional. Hal ini ditindak lanjuti dengan instansi pemerintah yaitu Kementerian Hukum dan HAM dalam dua bentuk Peraturan Menteri Hukum dan HAM di tahun 2018 mengenai keikutsertaan perancang didalam pembentukan dan pengharmonisasian peraturan. perundang undangan.

Pertama, Peraturan Menteri Hukum dan HAM Nomor 22 Tahun 2018 mengatur tentang wewenang perancang dalam harmonisasi rancangan peraturan perundang undanga yang dibentuk di daerah selanjutnya disebut Permenkumham Nomor 22/2018. Kedua , Peraturan Menteri Hukum dan HAM No 23 Tahun 2018 Tentang Pengharmonisasian Rancangan Peraturan Menteri, Rancangan Peraturan Lembaga Pemerintah Nonkementerian,Atau Rancangan Peraturan Dari Lembaga Non Struktural Oleh Perancang Peraturan Perundang-undangan Akan tetapi dengan ditetapkan peraturan tersebut menimbulkan protes dari kementerian pemerintah lainnya. Melangkah dari uraian latar belakang diatas, penulis hendak memaparkan sedikit mengenai Keabsahan permenkumham nomor 22/2018 tentang pengharmonisasian rancangan peraturan perundang-undangan yang dibentuk di daerah oleh perancang peraturan perundang-undangan, dan Batasan wewenang Kemenkumham melakukan harmonisasi peraturan daerah. Penulisan ini mengacu pada jenis penelitian hukum dilakukan dengan cara meneliti dan menganalisa norma-norma hukum dalam peraturan perundang-undangan yang berlaku terkait 
dengan isu hukum yang akan diteliti serta bukan hanya untuk mencari knowabout, tetapi know-how dalam ajaran ilmu hukum. ${ }^{10}$ Menurut Cohen menyatakan penelitian kegiatan know-how, dimaknai untuk memecahkan isu hukum yang ada bukan hanya sebatas untuk mengetahui sesuatu. Dalam melakukan penelitian hukum bukan sekedar proses menemukan hukum yang berlaku dalam kegiatan hidup bermasyarakat. Lebih dari itu, penelitian hukum ini juga merupakan proses menciptakan hukum untuk mengatasi masalah yang dihadapi. ${ }^{11}$ Oleh sebab jenis penelitian tersebut, metode yang digunakan studi kepustakaan, dengan pendekatan konsep dan pendekatan perundang-undangan, serta menggunakan analisis deskriptif.

\section{Keabsahan Permenkumham Nomor 22 Tahun 2018.}

Menurut Philppus. M. Hadjon, ${ }^{12}$ "Keabsahan tindakan pemerintah terdiri atas wewenang, subtansi dan prosedur. Salah satu contoh dari tindakan pemerintah tersebut adalah wewenang menetapkan peraturan menteri. Dalam konteks keberadaan peraturan menteri di Indonesia, Menurut pendapat H.A.S. Natabaya yang mengutip dari pendapat Abdul. Hamid.S.A materi muatan peraturan menteri tersebut meliputi: ${ }^{13}$

1. peraturan menteri dikeluarkan atas dasar wewenang menteri yang bersumber dari sifat wewenang derivatif presiden;

2. peraturan menteri tidak mengatur lebih lanjut dari Undang-Undang Sepanjang tidak ada pengaturan lebih lanjut dari peraturan pemerintah (pp) dan/atau peraturan presiden;

3. peraturan menteri tidak dilegasikan oleh peraturan pemerintah (pp) sepanjang tidak diatur lebih lanjut dengan peraturan presiden;

4. Sepanjang tidak difungsikan memperjelas peraturan presiden seyogyanya peraturan menteri bersifat mengatur ke dalam.

Menurut H.A.S Natabaya menyatakan di dalam materi muatan peraturan menteri meliputi: ${ }^{14}$

\footnotetext{
${ }^{10}$ Peter.M.Marzuki, Penelitian Hukum, Cetakan (Prenada Media Group 2017).[60].

11 ibid.[61].

${ }^{12}$ Philipus.M.Hadjon,'Fungsi Normatif Hukum Administrasi dalam Mewujudkan Pemerintahan yang Bersih' (1994), Orasi Ilmiah Pengukuhan Guru Besar Ilmu Hukum, Fakultas Hukum Universitas Airlangga.[7].

13 H.A.S.Natabaya, Sistem Peraturan Perundang-Undangan Indonesia (Sekjend Mahkamah Konstitusi 2006).[177].

14 ibid.[177-178].
} 
1. Menteri memiliki tiga wewenang untuk membuat keputusan, yaitu: Pertama, penetapan atau (beschikking). contoh dari keputusan penetapan ialah mengangkat pejabat tertentu di dalam lingkungan kerja menteri yang bersangkutan. Kedua, aturan kebijakan (beleidsregls). Keputusan ini pada umumnya tidak berpijak peraturan perundang-undangan melainkan berpijak pada wewenang. Diskresi (Freis Emessen) dengan catatan aturan kebijakan tersebut tidak bertentangan dengan peraturan perundang-undangan yang berlaku, kemudian tetap memperhatikan (AUPB), yaitu asas-asas umum penyelenggaraan pemerintahan yang baik/patut dan tetap dibatasi oleh wewenang yang dimiliki oleh menteri yang membuat aturan kebijakan. Ketiga, keputusan yang bersifat peraturan. (regeling). atau keputusan yang mengatur sepanjang wewenang yang dimilki untuk membuat adalah sumbernya delegatif/derivatif dari wewenang presiden hal ini konsekuensi dari menteri sebagai pejabat yang diangkat presiden.

2. Peraturan menteri sepanjang/dalam keadaan tertentu. berdasarkan wewenang menteri yang dimiliki bersumber langsung pada undang-undang tanpa.melalui pengaturan lebih lanjut. dari peraturah pemerintah. dan/atau. peraturan. Presiden. hal ini disebabkan karena substansi tidak layak secara teknis melalui peraturan pemerintah dan/atau peraturan presiden. contoh dari peraturan menteri tesebut adalah. undang-undang mengenai narkotika yaitu UU No. 27 Tahun. 1977. Disini terdapat peraturan menteri yang mengatur lebih lanjut dari undang-undang tersebut. contoh berikutnya Undang-Undang mengenai pemerintahan daerah UU. No. 23 Tahun. 2014 Tentang Pemda. disini terdapat peraturan Menteri Dalam Negeri yang mengatur lebih lanjut dari ketentuan lebih lanjut Undang-Undang pemda tersebut.

Negara memiliki cara untuk membuat keputusan didalam organisasi kekuasaan umum pertama peraturan, keputusan, dan vonis. ${ }^{15}$ Berdasarkan sifatnya peraturan mengikat secara umum dan memiliki fungsi untuk memeberikan pengarturan berkaitan hal-hal yang bersifat umum disebut hukum yang bersifat in abstracto atau general norm. ${ }^{16}$ Wujud dari peraturan salah satunya ialah peraturan

\footnotetext{
15 Jimly.Asshiddiqie, Perihal Undang-Undang (Konstitusi Pers 2006).[9].

16 SF.Marbun dan Moh.Mahfud, Pokok-Pokok Hukum Administrasi Negara, (Liberty 1987).[94].
} 
menteri yang bersifat umum karena kementerian Negara merupakan penjabaran wujud dari Negara.

Kedudukan atau posisi keberadaan kementerian Negara dianggap sangat penting dalam sistim ketatanegaraan Indonesia Menurut Jimly Asshiddiqie. ${ }^{17}$ Berdasarkan UUD NRI 1945 ketentuan kekuasaan pemerintahan Negara dipisah dengan keberadaan atau kedudukan kementerian Negara. Maka, sebelum amandemen Undang-Undang Dasar 1945 dijelaskan bahwa menteri bukan merupakan pejabat yang biasa, tetapi memiliki posisi tinggi sebagai pemimpin kegiatan eksekutif seharihari dalam bidang tertentu. 18 Menurut Maria Farida Indrati juga menyatakan hal yang sama bahwa menteri bukanlah pegawai biasa, meskipun posisi menteri bergantung pada Presiden. Berdasarkan UUD NRI 1945 Pasal 17 ayat (3) menyatakan bahwa Para Menteri. Memiliki tugas memimpin jalannya kekuasaan pemerintahan di bidangnya masing-masing. ${ }^{19}$ Kemudian, berdasarkan Undang-Undang Nomor. 39. Tahun. 2008. tentang kementerian Negara. Pasal 4 ayat (1) urusan tertentu di bidang pemerintahan dilakasanakan oleh setiap Menteri, urusan tersebut meliputi: pertama berkaitan dengan koordinasi, penajaman dan sikronisasi program yang dibuat pemerintah, kedua terkait dengan urusan yang disebutkan nama kementeriannya secara langsung dan tegas dalam undang-undang dasar Negara republik Indonesia, ketiga urusan tersebut sumbernya/ruang lingkupnya. disebutkan didalam undang-undang dasar Negara republik Indonesia. serta didalam menjalankan tugas dan fungsinya menteri tersebut diberikan wewenang membentuk peraturan sebagai berikut $:^{20}$

a. Untuk mengatur terkait penyelenggaraan kekuasaan pemerintahan di bidangnya;

b. Untuk mengatur terkait lebih lanjut ketentuan dalam peraturan presiden;

c. Untuk mengatur terkait lebih lanjut ketentuan dalam Undang-undang yang tegas menyebutnya;

d. Untuk mengatur terkait lebih lanjut ketentuan dalam PP yang tegas-tegas menyebutnya.

\footnotetext{
17 Jimly.Asshiddiqie, Perkembangan Dan Konsolidasi Lembaga Negara Pasca Reformasi, (Sinar Grafika 2013).[174].

18 ibid, [175].

${ }^{19}$ Maria Farida Indrati S, Ilmu Perundang-Undangan (Jenis, Fungsi, Materi Muatan), (Kanisius 2007).[155].

20 Op.Cit.[225].
} 
Berdasarkan dari pendapat ahli dan uraian diatas, dapat kita pahami peraturan menteri dalam sistem penormaan hukum di Negara Indonesia. selanjutnya, untuk menganalisa persoalan keabsahan Permenkumham Nomor 22/2018 berdasarkan wewenang yang dimiliki Menkumham. Permenkumham Nomor 22/2018 merupakan peraturan pelaksanaan dari Pasal 3 PP Nomor 59 Tahun 2015 juncto Pasal 98 Undang-Undang Nomor 12 Tahun 2011. Hierarki dari Peraturan Menteri Hukum dan Hak Asasi Manusia berada di bawah Undang-Undang dan Peraturan Menteri Hukum dan Hak Asasi Manusia termasuk dalam jenis peraturan perundangundangan sebagaimana dimaksud dalam Pasal 8 Undang-Undang Nomor 12 Tahun 2011 sehingga materi muatannya tidak boleh bertentangan dengan Undang-Undang Nomor 12 Tahun 2011 dan PP Nomor 59 Tahun 2015. Dalam Pasal 3 Peraturan Menteri Hukum dan Hak Asasi Manusia Republik Indonesia Nomor 22 Tahun 2018 yang berbunyi:

"Rancangan peraturan rancangan peraturan daerah provinsi, rancangan peraturan daerah kabupaten/kota, rancangan peraturan gubernur, rancangan peraturan bupati/walikota, rancangan peraturan desa atau yang setingkat, dan peraturan kepala desa atau rancangan peraturan yang setingkat disampaikan secara tertulis kepada Direktur Jenderal sebagai pembina Perancang melalui Kepala Kantor Wilayah untuk dilakukan Pengharmonisasian”.

Pasal diatas bertentangan dengan Pasal 2 dan Pasal 3 PP Nomor 59 Tahun 2015 tentang Keikutsertaan Perancang Peraturan Perundang-undangan dalam Pembentukan Peraturan Perundang-undangan dan Pembinaannya dimana berbunyi sebagai berikut:

Pasal 2

(1) Perancang berkedudukan sebagai pelaksana teknis fungsional Perancang pada unit kerja yang mempunyai tugas dalam Pembentukan Peraturan Perundang-undangan dan penyusunan instrumen hukum lainnya;

(2) Unit kerja sebagaimana dimaksud pada ayat (1) berada di lingkungan lembaga negara, kementerian, lembaga pemerintah nonkementerian, lembaga nonstruktural, Pemerintah Daerah Provinsi, dan Pemerintah Daerah Kabupaten/Kota.

Pasal 3

(1) Perancang mempunyai tugas menyiapkan, mengolah, dan merumuskan Rancangan Peraturan Perundang-undangan serta instrumen hukum 
lainnya;

(2) Dalam melaksanakan tugas sebagaimana dimaksud pada ayat (1), Perancang harus melakukan pengharmonisasian.

Karena mengubah subjek hukum yang pada awalnya “...Perancang harus melaksanakan pengharmonisasian” menjadi “...disampaikan secara tertulis kepada Direktur Jenderal sebagai Pembina Perancang untuk diharmonisasikan". ${ }^{21}$ Perancang yang dimaksud dalam Pasal 3 PP Nomor 59 Tahun 2015 adalah Perancang yang berada di lingkungan lembaga negara, kementerian, lembaga pemerintah nonkementerian, lembaga nonstruktural, Pemerintah Daerah Provinsi, dan Pemerintah Daerah Kabupaten/Kota jadi bukan ditujukan kepada Perancang yang berada di lingkungan Direktorat Jenderal Peraturan Perundang-undangan saja. Dalam PP Nomor 59 Tahun 2015 tidak mendelegasikan secara khusus kegiatan pengharmonisasian peraturan perundang-undangan kepada Direktur Jenderal Peraturan Perundang-undangan, PP 59/2015 hanya mengatur mengenai perintah kepada lembaga negara, kementerian, lembaga pemerintah nonkementerian, lembaga nonstruktural, Pemerintah Daerah Provinsi, dan Pemerintah Daerah Kabupaten/Kota untuk mengikutsertaan Perancang Peraturan Perundang-undangan dalam setiap tahapan pembentukan peraturan perundang-undangan. Keikutsertaan Perancang Peraturan Perundang-undangan menjadi syarat formil dalam setiap tahapan pembentukan peraturan perundang-undangan. Dalam PP 59/2015 juga diatur bilamana suatu lembaga negara, kementerian, lembaga pemerintah nonkementerian, lembaga nonstruktural, Pemerintah Daerah Provinsi, dan Pemerintah Daerah Kabupaten/Kota belum memiliki Perancang Peraturan Perundang-undangan, maka dapat mengikutsertakan Perancang dari lembaga, kementerian, atau Pemerintah Daerah lain untuk memenuhi syarat formil tersebut.

Ruang lingkup wewenang Direktur Jenderal Peraturan Perundang-undangan sebagai Pembina Perancang sebagaimana diatur dalam Pasal 17 ayat (1) PP Nomor 59 Tahun 2015 tidak mencakup kewenangan melaksanakan pengharmonisasian Rancangan Peraturan Menteri, Rancangan Peraturan Lembaga Pemerintah 
Nonkementerian, atau Rancangan Peraturan dari Lembaga Nonstruktural, sebagaimana berbunyi sebagai berikut:

\section{Pasal 17}

(1) Pembinaan jabatan fungsional Perancang mencakup aspek:

a. Perumusan kebijakan teknis pembinaan Perancangan;

b. Pembinaan kompetensi dan fasilitasi pengembangan karier Perancang;

c. Pengawasan terhadap penerapan etika profesi Perancang;

d. Pemantauan dan evaluasi pengelolaan jabatan fungsional Perancang; dan

e. Pemantauan dan evaluasi pengelolaan Perancang;

Penjelasan Pasal 17

(1) Huruf a: Yang dimaksud dengan "pembinaan Perancangan" adalah upaya penjaminan kualitas Perancang antara lain melalui kurikulum, penyelenggaraan pendidikan dan pelatihan, penyelenggaraan uji kompetensi Perancang, dan peningkatan kompetensi lainnya; Sehingga ketentuan dalam Pasal 4 Peraturan Menteri Hukum dan Hak Asasi Manusia Republik Indonesia Nomor 23 Tahun 2018 bertentangan dengan Pasal 17 ayat (1) Peraturan Pemerintah Nomor 59 Tahun 2015. Dalam Pasal 7 ayat (2) Peraturan Menteri Hukum dan Hak Asasi Manusia Republik Indonesia Nomor 22 Tahun 2018 yang berbunyi sebagai berikut:

"Untuk menjaga objektifitas pembahasan dalam rapat Pengharmonisasian, Perancang yang berasal dari instansi Pemrakarsa tidak dapat ditugaskan oleh Direktur Jenderal untuk memimpin rapat Pengharmonisasian”.

Bertentangan dengan Pasal 4 PP Nomor 59 Tahun 2015 dan penjelasannya yang berbunyi sebagai berikut:

"Perancang sebagaimana dimaksud dalam Pasal 3 wajib bersikap profesional sesuai dengan disiplin ilmu hukum, ilmu perundang-undangan, dan disiplin ilmu lain yang dibutuhkan."; "Yang dimaksud dengan "bersikap profesional" adalah bahwa Perancang dalam melaksanakan tugasnya sesuai dengan keahlian, keterampilan, dan kompetensi yang dimiliki serta mempunyai integritas".

Dalam Pasal 7 ayat (2) Peraturan Menteri Hukum dan Hak Asasi Manusia Republik Indonesia Nomor 22 Tahun 2018 tidak mencerminkan keadilan secara proporsional antara Perancang Peraturan Perundang-undangan di dalam dan di luar Kementerian Hukum dan Hak Asasi Manusia. Materi muatan dalam Pasal 7 ayat (2) mengandung unsur muatan diskriminatif terhadap Perancang Peraturan Perundang- 
undangan di lingkungan Pemerintah Daerah yang dianggap tidak objektif dalam melaksanakan tugas dan fungsinya. Perancang Peraturan Perundang-undangan Kementerian Hukum dan Hak Asasi Manusia juga tidak memiliki kapasitas untuk memimpin rapat harmonisasi dalam suatu Pemerintah Daerah dikarenakan Perancang Peraturan Perundang-undangan merupakan jabatan fungsional yang secara struktur kedudukannya berada dibawah koordinasi dari jabatan pimpinan tinggi dan jabatan administrasi berdasarkan Undang-Undang Nomor 5 Tahun 2014 tentang Aparatur Sipil Negara.

Dalam lingkup Pemerintah Daerah sebenarnya telah memiliki Pejabat Fungsional Perancang Peraturan Perundang-undangan yang memiliki kompetensi dalam melakukan pengharmonisasian peraturan perundang-undangan, sehingga pemberlakuan Peraturan Menteri Hukum dan Hak Asasi Manusia Republik Indonesia Nomor 22 Tahun 2018 mengakibatkan alur pembentukan peraturan perundang-undangan di lingkup Pemerintah Daerah menjadi lebih panjang, tidak efektif dan tidak efisien. Selain membuat alur birokrasi menjadi lebih panjang, tidak efektif dan tidak efisien, pemberlakuan Peraturan Menteri Hukum dan Hak Asasi Manusia Republik Indonesia Nomor 22 Tahun 2018 telah merendahkan profesionalisme, objektifitas, kapabilitas kinerja serta dapat mengkerdilkan peran Perancang Peraturan Perundangundangan di lingkup internal Pemerintah Daerah dalam melakukan pengharmonisasian peraturan perundang-undangan yang menjadi tugas dan fungsi sehari-hari.

Pembentukan Peraturan Menteri Hukum dan Hak Asasi Manusia Republik Indonesia Nomor 22 Tahun 2018 menyimpang dari tujuan awal ditetapkannya PP Nomor 59 Tahun 2015 dimana untuk meningkatkan peran Perancang dalam setiap tahapan Pembentukan Peraturan Perundang-undangan dan mewujudkan sumber daya manusia yang profesional dan memiliki kompetensi di bidang Peraturan Perundang-undangan. Sasaran dari tujuan tersebut tentu saja bukan hanya bagi Perancang Peraturan Perundang-undangan di dalam lingkup Kementerian Hukum dan Hak Asasi Manusia tetapi juga bagi Perancang Peraturan Perundang-undangan di lingkungan Pemerintah Daerah. Oleh karena itu, sehubungan dengan pokok 
persoalan dalam tulisan ini, adalah tidak sah keabsahan substansi, prosedur, serta wewenang pembentukan Permenkumham tersebut.

Ketidakabsahan pembentukan Permenkumham Nomor 22/2018 mengakibatkan tidak memiliki kekuatan hukum mengikat pada peraturan menteri tersebut serta tidak ada pengakuan peraturan menteri tersebut. Hal ini atas dasar tersebut ketentuan didalam UU No. 12 Tahun 2011. Dalam Pasal 8 ayat (1) tentang pembentukan peraturan perundang-undangan menyatakan:

"Jenis peraturan perundang-undangan selain dalam ketentuan ini, antara lain peraturan yang ditetapkan oleh MPR, DPR, DPD, MA, MK, BPK, KY, Bank Indonesia, Menteri, Kepala Badan, Lembaga, atau Komisi yang setingkat yang dibentuk oleh UU atau pemerintah atas perintah UU, DPRD Provinsi, Gubernur, DPRD Kabupaten/Kota, Bupati/Walikota, Kepala Desa atau yang setingkat".

Kemudian Pasal 8 ayat (2) UU. No. 12 Tahun 2011 menyatakan bahwa:

"Jenis peraturan perundang-undangan sebagaimana dalam ketentuan ayat (1), tersebut diakui keberadaannya dan mempunyai kekuatan hukum mengikat sepanjang diperintahkan oleh peraturan perundang-undangan yang lebih tinggi atau dibentuk berdasarkan wewenang”.

Sehingga, Permenkumham Nomor 22/2018 pada saat dibentuk tidak memenuhi syarat alternatif sebagaimana dimaksud dalam Pasal 8 ayat (1) dan (2) UU. No. 12 Tahun 2011, sedangkan unsur-unsur peraturan perundang-undangan di dalam Pasal 1 angka 2 UU. No. 12 Tahun 2011 disebutkan bahwa: "Peraturan Perundangundangan adalah peraturan tertulis yang memuat norma hukum yang mengikat secara umum dan dibentuk atau ditetapkan oleh lembaga Negara atau pejabat yang berwenang melalui prosedur yang ditetapkan dalam peraturan perundangundangan". maka, unsur-unsur dari sebuah peraturan terdiri atas:1.Tertulis; 2.Memuat norma hukum yang mengikat secara umum; 3.Dibentuk atau ditetapkan oleh lembaga Negara atau pejabat yang berwenang; dan 4.Melalui prosedur yang ditetapkan dalam peraturan perundang-undangan

Keempat unsur-unsur diatas merupakan hal yang bersifat kumulatif artinya seluruh syarat wajib dipenuhi. Melihat ketentuan diatas lembaga Negara atau pejabat yang berwenag merupakan unsur utama yang akan menimbulkan akibat hukum dari syarat-syarat tersebut yakni batal demi hukum atau dapat dibatalkan. 
Dapat dibatalkan berarti akibat-akibat sebelum adanya pembatalan atau pencabutan peraturan perundang-undangan tetap diakui. Sedangkan batal demi hukum berarti bahwa bahwa akibat - akibat yang ada di anggap tidak ada dan dikembalikan seperti semula. Menurut Sukardi, sifat putusan batal demi hukum (nul and void atau van rechtswege nietig) terhadap peraturan perundang - undangan tidak dikenal di dalam sistem hukum Indonesia, tetapi yang dipakai adalah sifat dapat dibatalkan (vernietigbaar) adapaun asas yang digunakan adalah asas praduga keabsahan (praduga rechtmatigheid) karena di dalam kepustakaan dikenal dengan asas presumtio iustae causa yang maknanya adalah bahwa setiap tindakan pemerintah adalah sah sepanjang belum dibuktikan sebaliknya", ${ }^{22}$

Berdasarkan penjelasan di atas penulis berpendapat bahwa katagori perbuatan hukum Menkumham dikategorikan dalam cacat wewenang, cacat prosedur dan cacat substansi. Maka akibat hukum dari ketentuan peraturan menteri yang tidak sesuai dan bertentangan dengan Peraturan Perundangan-undangan yang lebih tinggi adalah dapat dibatalkan. Namun, disini harus dibedakan antara berlakunya prinsip/asas presumtio iustae causa didalam konteks peraturan menteri dengan konteks keputusan tata usaha Negara (KTUN) yang dibuat oleh menteri ketika membuat suatu keputusan. Apabila dalam keputusan yang berupa peraturan menteri prinsip/asas presumtio iustae causa tersebut daya lakunya bagi semua pihak yang terikat didalamnya syarat keabsahan yaitu wewenang, subtansi, dan prosedur. Hal ini berbeda dengan KTUN tidak berlaku terhadap untuk cacat wewenang KTUN yang akibatnya adalah batal demi hukum, sedangkan prinsip/ asas tersebut untuk cacat prosedur, dan subtansi. Penerapan akibat hukum batal demi hukum akan menimbulkan dampak ketidakpastian hukum dan tidak efisien didalam jalannya pemerintahan hal ini disebabkan peraturan menteri bersifat mengatur berlaku kepada para pihak yang terikat pada ruang lingkup peraturan menteri tersebut secara umum (general) dan berlaku terus menerus sejak ditetapkan atau diundangkan berlaku. Namun, berbeda jika penerapan batal demi

\footnotetext{
${ }^{22}$ Sukardi, Pengawasan dan Pembatalan Peraturan Daerah (Genta Publishing 2016).[145].
} 
hukum terhadap keputusan tata usaha Negara /KTUN yang bersifat sekali selesai (enmahlig) dan mengikat kepada pemohon keputusan tata usaha Negara/KTUN saja (individual) maka akibat batal demi hukum lebih efektif untuk diterapkan karena memungkinkan untuk dikembalikan pada kondisi semula dan daya jangkaunya/ruang lingkupnya tidak luas.

Sebagai konsep hukum publik wewenang sekurang - kurangnya terdiri atas tiga komponen, yaitu pengaruh, dasar hukum dan konformitas hukum. Komponen pengaruh ialah bahwa penggunaan wewenang dimaksudkan untuk mengendalikan perilaku subyek hukum. ${ }^{23}$ Komponen dasar hukum, bahwa wewenang itu harus selalu ditunjuk dasar hukumnya dan komponen konformitas hukum, mengandung makna adanya standar wewenang, yaitu standar umum (semua jenis wewenang) dan standar khusus (untuk jenis wewenang tertentu)". ${ }^{24}$ Terdapat tiga faktor materi (subtansi), waktu (tempus), dan tempat (locus) didalam penerapan wewenang. Artinya dianggap tidak berwenang (onbevoegdheid) ketika melebihi batas-batas yang telah ditentukan. Keadaan atau tindakan yang melebihi dari batas-batas ditentukan disebut sebagai berikut, pertama wewenang melebihi batas wilayah (onbevoegdheid ratione loci); kedua, wewenang melebihi batas waktu (onbevoegdheid ratione temporis); ketiga, wewenang melebihi batas subtansi (onbevoegdheid ratione materiae). Secara prinsip pembagian wewenang (power limit power) yaitu wewenang yang satu dalam hal ini pengharmonisasian produk hukum di daerah oleh Kemenkumham dibatasi oleh wewenang yang lain yaitu Kemendagri selaku pembina dan pengawas dari pembentukan produk hukum daerah yang di dalam prosesnya terdapat pengharmonisasian. Sehingga menurut prinsip pembagian wewenang sebaiknya tidak boleh tumpang tindih, harus jelas dasar hukumnya, tidak boleh ada kekosongan hukum antara Kemenkumham dengan Kemendagri dalam pengharmonisasian produk hukum daerah. Lebih lanjut mekanisme pembentukan peraturan perundang-undangan, wewenang Kemenkumham dalam melaksanakan pengharmonisasian peraturan perundang-undangan berdasarkan Undang-Undang

\footnotetext{
${ }^{23}$ Philipus M Hadjon, 'Tentang Wewenang' (1997) Yuridika.[1].

${ }^{24}$ ibid.[1].
} 
Nomor 12 Tahun 2011 beserta perubahannya Undang-undang Nomor 15 Tahun 2019 terbatas pada peraturan daerah yang berasal dari Gubernur, Bupati, dan Walikota. Sedangkan pengharmonisasian peraturan daerah yang berasal dari DPRD Provinsi, DPRD Kabupaten dan DPRD Kota bukan wewenang dari Kemenkumham sebagaimana dijelaskan melalui tabel dibawah ini :

\begin{tabular}{|c|c|c|}
\hline $\begin{array}{c}\text { Obyek } \\
\text { Harmonisasi }\end{array}$ & $\begin{array}{c}\text { UU No } 12 \text { Tahun } \\
2011\end{array}$ & Keterangan \\
\hline \multirow[t]{2}{*}{$\begin{array}{l}\text { Peraturan } \\
\text { Provinsi }\end{array}$} & Pasal 58 Ayat (1) & $\begin{array}{l}\text { Pengharmonisasian, pembulatan, dan pemantapan } \\
\text { konsepsi Rancangan Peraturan Daerah Provinsi } \\
\text { yang berasal dari DPRD Provinsi dikoordinasikan } \\
\text { oleh alat kelengkapan DPRD Provinsi yang khusus } \\
\text { menangani bidang legislasi. }\end{array}$ \\
\hline & Pasal 58 Ayat (2) & $\begin{array}{l}\text { Pengharmonisasian, pembulatan, dan pemantapan } \\
\text { konsepsi Rancangan Peraturan Daerah Provinsi yang } \\
\text { berasal dari Gubernur dikoordinasikan oleh biro } \\
\text { hukum dan dapat mengikutsertakan instansi vertikal } \\
\text { dari kementerian yang menyelenggarakan urusan } \\
\text { pemerintahan di bidang hukum. }\end{array}$ \\
\hline $\begin{array}{l}\text { Peraturan Daerah } \\
\text { Kabupaten/ Kota }\end{array}$ & Pasal 63 & $\begin{array}{l}\text { Ketentuan mengenai penyusunan Peraturan Daerah } \\
\text { Provinsi sebagaimana dimaksud dalam Pasal } 56 \\
\text { sampai dengan Pasal } 62 \text { berlaku secara mutatis } \\
\text { mutandis terhadap penyusunan Rancangan Peraturan } \\
\text { Daerah Kabupaten/Kota. }\end{array}$ \\
\hline $\begin{array}{c}\text { Obyek } \\
\text { Harmonisasi }\end{array}$ & $\begin{array}{l}\text { Undang-undang } \\
\text { No } 15 \text { Tahun } 2019\end{array}$ & Keterangan \\
\hline \multirow[t]{2}{*}{$\begin{array}{l}\text { Peraturan } \\
\text { Provinsi }\end{array}$} & Pasal 58 Ayat (1) & $\begin{array}{l}\text { Pengharmonisasian, pembulatan, dan pemantapan } \\
\text { konsepsi Rancangan Peraturan Daerah Provinsi yang } \\
\text { berasal dari DPRD Provinsi dikoordinasikan oleh alat } \\
\text { kelengkapan DPRD Provinsi yang khusus menangani } \\
\text { bidang legislasi. }\end{array}$ \\
\hline & Pasal 58 Ayat (2) & $\begin{array}{l}\text { Pengharmonisasian, pembulatan, dan pemantapan } \\
\text { konsepsi Rancangan Peraturan Daerah Provinsi } \\
\text { yang berasal dari Gubernur dikoordinasikan oleh } \\
\text { kementerian atau lembaga yang menyelengarakan } \\
\text { urusan pemerintahan di bidang Pembentukan } \\
\text { Peraturan Perundang-undangan. }\end{array}$ \\
\hline
\end{tabular}

Sedangkan wewenang Kemenkumham berdasarkan Peraturan Presiden Nomor 87 Tahun 2014 terkait pelaksanaan harmonisasi peraturan perundang-undangan terbatas pada Peraturan Daerah Provinsi yang berasal dari Gubernur, Peraturan Daerah Kabupaten/ Kota yang berasal dari Bupati/Walikota, kecuali Peraturan Daerah Provinsi yang berasal dari DPRD Provinsi, dan DPRD Kabupaten/ Kota, sebagaimana dijelaskan melalui tabel dibawah ini: 


\begin{tabular}{|c|c|c|c|}
\hline \multicolumn{2}{|c|}{$\begin{array}{c}\text { Obyek } \\
\text { Harmonisasi }\end{array}$} & Pasal & Keterangan \\
\hline \multirow{8}{*}{\multicolumn{2}{|c|}{$\begin{array}{l}\text { Peraturan } \\
\text { Provinsi }\end{array}$}} & Pasal 75 & Ayat (1) Sekertaris Daerah Provinsi menugaskan \\
\hline & & & $\begin{array}{l}\text { kepala biro hukum untuk mengkoordinasikan } \\
\text { pengharmonisasian, pembulatan, dan pemantapan } \\
\text { konsepsi Rancangan Peraturan Daerah Provinsi } \\
\text { sebagaimana dimaksud dalam Pasal } 74 \text {. }\end{array}$ \\
\hline & & & $\begin{array}{l}\text { Ayat (2) Dalam mengkoordinasikan } \\
\text { pengharmonisasian, pembulatan, dan pemantapan } \\
\text { konsepsi sebagaimana dimaksud pada ayat (1), } \\
\text { kepala biro hukum dapat mengikutsertakan instansi } \\
\text { vertikal dari kementerian yang menyelenggarakan } \\
\text { urusan pemerintahan di bidang hukum. }\end{array}$ \\
\hline & & Pasal 77 & $\begin{array}{l}\text { Ketentuan mengenai penyusunan Peraturan } \\
\text { Daerah di lingkungan Pemerintah Daerah } \\
\text { Provinsi sebagaimana dimaksud dalam Pasal } 70 \\
\text { sampai dengan Pasal } 76 \text { berlaku secara mutatis } \\
\text { mutandis terhadap penyusunan Peraturan Daerah } \\
\text { di lingkungan Pemerintah Daerah Kabupaten/ } \\
\text { Kota. }\end{array}$ \\
\hline & & Pasal 81 & Ayat (1) Pimpinan DPRD Provinsi menyampaikan \\
\hline & & & $\begin{array}{l}\text { Rancangan Peraturan Daerah Provinsi } \\
\text { sebagaimana dimaksud dalam Pasal } 79 \text { ayat (1) } \\
\text { kepada Balegda untuk dilakukan pengkajian. }\end{array}$ \\
\hline & & & $\begin{array}{l}\text { Ayat (2) Pengkajian sebagaimana dimaksud } \\
\text { pada ayat (1) dilakukan dalam rangka } \\
\text { pengharmonisasian, pembulatan, dan pemantapan } \\
\text { konsepsi Rancangan Peraturan Daerah Provinsi. }\end{array}$ \\
\hline & & Pasal 86 & $\begin{array}{l}\text { Ketentuan mengenai penyusunan Peraturan } \\
\text { Daerahdilingkungan DPRD Provinsi sebagaimana } \\
\text { dimaksud dalam Pasal } 78 \text { sampai dengan Pasal } \\
85 \text { berlaku secara mutatis mutandis terhadap } \\
\text { penyusunan Peraturan Daerah di lingkungan } \\
\text { DPRD Kabupaten/Kota. }\end{array}$ \\
\hline
\end{tabular}

Selanjutnya wewenang pembentukan produk hukum daerah oleh Kemendagri berdasarkan Peraturan Menteri Dalam Negeri (Permendagri ) Nomor 120 tahun 2018 tentang perubahan atas peraturan menteri dalam negeri Nomor 80 Tahun 2015 tentang pembentukan produk hukum daerah Pasal 3 menyatakan bahwa produk hukum bentuknya peraturan yaitu : 
“a. Perda (peraturan daerah) provinsi dan/atau kabupaten/kota;,b. Perkada (peraturan kepala daerah) provinsi dan/atau kabupaten/kota; Peraturan DPRD (dewan perwakilan rakyat daerah) provinsi dan/atau kabupaten/kota".

Sedangkan Produk hukum berupa keputusan berdasarkan Pasal 9 Permendagri Nomor 80 Tahun 2015 meliputi:

"keputusan kepala daerah provinsi dan/atau kabupaten/kota; keputusan. DPRD (dewan perwakilan rakyat daerah); keputusan pimpinan DPRD (dewan perwakilan rakyat daerah); keputusan badan kehormatan DPRD (dewan perwakilan daerah)".

Peraturan Mendagri diatas membagi dua jenis produk hukum berupa peraturan dan keputusan, Terkait dengan dua bentuk produk hukum tersebut, Maria Farida Indrati menyebutkan bahwa keputusan (beschikkiking) bersifat sekali-selesai (enmahlig), sedangkan peraturan (regeling) selalu berlaku terus-menerus (dauerhaftig)". ${ }^{25}$ Maka didalam memaknai rancangan peraturan perundang-undangan yang dibentuk di daerah bukan hanya secara terbatas meliputi peraturan daerah yang berasal dari usulan Gubernur, Walikota dan Bupati, DPRD Provinsi, DPRD Kabupaten, DPRD Kota melainkan dapat berupa Produk hukum lainnya yang berupa keputusan dari Pemerintah Daerah tersebut.

\section{Kesimpulan}

Keabsahan Permenkumham Nomor 22/2018 adalah tidak sah karena dasar hukum dan wewenang untuk mengaharmonisasi rancangan peraturan perundang-undangan yang dibentuk di daerah tidak didasari substansinya atas penjabaran perundang-undangan yang lebih tinggi. Wewenang harmonisasi oleh Kemenkumham hanya sebatas peraturan daerah yang berasal dari Gubernur, Bupati, dan Walikota tidak termasuk peraturan daerah dari DPRD Provinsi, DPRD Kabupaten, dan DPRD Kota serta produk hukum lainnya yang dibentuk di daerah.

${ }_{25}$ Maria Farida Indrati S, Ilmu Perundang-Undangan (1) (Jenis, Fungsi, Materi, Muatan), (Kanisius 2007).[78]. 


\section{Daftar Bacaan}

\section{Buku}

E.Prajwalita Widiati dan N.Aji Utomo, Menjejakkan Legislasi Berbasis HAM (Komisi Nasional Hak Asasi Manusia 2016).

H.A.S Natabaya, Sistem Peraturan Perundang-Undangan Indonesia (Sekjend Mahkamah Konstitusi 2006).

Jimly Asshiddiqie, Perihal Undang-Undang (Konstitusi Pers 2006). Perkembangan Dan Konsolidasi Lembaga Negara Pasca Reformasi (Sinar Grafika 2013).

Maria Farida Indrati S, Ilmu Perundang-Undangan (Jenis, Fungsi, Materi Muatan) (Kanisius 2007).

Peter Mahmud Marzuki, Penelitian Hukum (Prenada Media Group 2017).

S.F.Marbun dan Moh.Mahfud, Pokok-Pokok Hukum Administrasi Negara (Liberty 1987).

Sukardi, Pengawasan dan Pembatalan Peraturan Daerah (Genta Publishing 2016).

\section{Jurnal}

Philipus M Hadjon, 'Tentang Wewenang' (1997) Yuridika.

\section{Makalah}

Philipus.M.Hadjon,'Fungsi Normatif Hukum Administrasi dalam Mewujudkan Pemerintahan yang Bersih' (1994), Orasi Ilmiah Pengukuhan Guru Besar Ilmu Hukum, Fakultas Hukum Universitas Airlangga.

\section{Laman}

Agus Sahbani,'Permenkumham Harmonisasi Peraturan Dinilai Konflik dengan UU' $(2018)<w w w . H u k u m o n l i n e . c o m / b e r i t a / b a c a / l t 5 b d c 39 c 5 d 3 a 98 /$ permenkumham-harmonisasi-peraturan-dinilai-konflik-dengan-uu>, diakses pada 12 Agustus 2019.

Biro hukum Kemendagri, 'Kajian Normatif Permenkumham 22 Tahun 2018 Berdasarkan Peraturan Perundang-Undangan Dan Asas Hukum'(2018) $<$ http:// keuda. kemendagri. go.id /asset /kcfinder /upload/ files/ Biro \% 20 Hukum\% 20 Kemendagri \% 20terkait\%20Permenkumham\%2022\%20 
Tahun\%202018.pdf>, diakses 1 Agustus 2019.

Dinas Komunikasi dan Informasi Pemerintah Provinsi Jawa Timur,'Bapperda DPRD Minta Permenkumham No 22/2018 Tak Batasi Kebebasan Daerah'(2018) <http://kominfo.jatimprov.go.id/read/umum/bapperda-dprdminta-permenkumham-no-22-2018-tak-batasi-kebebasan-daerah>, diakses 12 Agustus 2019.

Menteri Dalam Negeri,'Surat Edaran Permohonan Pencabutan Atas Permenkumham Nomor 22 Tahun 2018 dan Permenkumham Nomor 23 Tahun 2018'(2018)<http://jdih.setjen.kemendagri.go.id/materi/Surat\%20 Permohonan\%20pencabutan\%20permenkumham.pdf > diakses pada 12 Agustus 2019.

\section{Perundang-undangan}

Undang-Undang Dasar Negara Republik Indonesia Tahun 1945.

Undang-Undang Nomor 39 Tahun 2008 tentang Kementerian Negara (Lembaran Negara Republik Indonesia Tahun 2008 Nomor 166; Tambahan Lembaran Negara Republik Indonesia Nomor 4916).

Undang-Undang Nomor 12 Tahun 2011 tentang Pembentukan Peraturan Perundang -Undangan (Lembaran Negara Republik Indonesia Tahun 2011 Nomor 82; Tambahan Lembaran Negara Republik Indonesia Nomor 5234).

Undang-Undang Nomor 15 Tahun 2019 tentang Perubahan Atas Undang-Undang Nomor 12 Tahun 2011 tentang Pembentukan Peraturan Perundang-Undangan (Lembaran Negara Republik Indonesia Tahun 2019 Nomor 183; Tambahan Lembaran Negara Republik Indonesia Nomor 6398).

Undang - Undang Nomor 23 Tahun 2014 tentang Pemerintah Daerah (Lembaran Negara Republik Indonesia Tahun 2014 Nomor 244; Tambahan Lembaran Negara Republik Indonesia Nomor 5587).

Peraturan Pemerintah Nomor 59 Tahun 2015 tentang Keikutsertaan Perancang Peraturan Perundang-Undangan Dalam Pembentukan Peraturan PerundangUndangan Dan Pembinaannya (Lembaran Negara Republik Indonesia Tahun 2015 Nomor 189; Tambahan Lembaran Negara Republik Indonesia Nomor 5729).

Peraturan Presiden Nomor 87 Tahun 2014 tentang Pelaksanaan Undang-Undang Nomor 12 Tahun 2011 tentang Pembentukan Peraturan Perundang-Undangan (Lembaran Negara Republik Indonesia Tahun 2014 Nomor 199). 
Peraturan Menteri Dalam Negeri Republik Indonesia Nomor 80 Tahun 2015 tentang Pembentukan Produk Hukum Daerah (Berita Negara Republik Indonesia Tahun 2015 Nomor 2036).

Peraturan Menteri Dalam Negeri Republik Indonesia Nomor 120 Tahun 2018 tentang Perubahan Atas Peraturan Menteri Dalam Negeri Nomor 80 Tahun 2015 tantang Pembentukan Produk Hukum Daerah (Berita Negara Republik Indonesia Tahun 2018 Nomor 157).

Peraturan Menteri Hukum dan HAM Republik Indonesia Nomor 22 Tahun 2018 tentang Pengharmonisasian Rancangan Peraturan Perundang-Undangan Yang Dibentuk Di Daerah Oleh Perancang Peraturan Perundang-Undangan (Berita Negara Republik Indonesia Tahun 2018 Nomor 1133). 
Choirudin Abdul: Pengaturan Harmonisasi Rancangan...

--halaman ini sengaja dibiarkan kosong-- 